\title{
Dampak Covid-19 dan Pemanfaatan Insentif Pajak terhadap Keberlangsungan Usaha pada UMKM Tenun Troso Jepara
}

\author{
Mamik Indaryani ${ }^{1)}$, Nita Andriyani Budiman ${ }^{2 *}$, Sri Mulyani ${ }^{3)}$ \\ 1) Program Studi Manajemen, Fakultas Ekonomi dan Bisnis, Universitas Muria Kudus \\ Gondangmanis, Bae, Kudus, Jawa Tengah 59327 \\ ${ }^{2 * 3)}$ Program Studi Akuntansi, Fakultas Ekonomi dan Bisnis, Universitas Muria Kudus \\ Gondangmanis, Bae, Kudus, Jawa Tengah 59327 \\ E-mail: nita.andriyani@umk.ac.id ${ }^{2 *}$
}

\begin{abstract}
ABSTRAK
Tenun Troso Jepara merupakan salah satu produk unggulan di Kabupaten Jepara. Kondisi keuangan UMKM Tenun Troso Jepara selama pandemi Covid-19 banyak yang mengalami keterpurukan dan hal ini akan mengancam keberlangsungan usaha para pelaku UMKM Tenun Troso Jepara. Pemerintah melalui PMK No. 86 Tahun 2020 sudah menetapkan pemberian insentif pajak bagi UMKM yang berdampak Covid-19. Tujuan dari penelitian ini adalah untuk menganalisis dampak Covid-19 dan pemanfaatan insentif pajak terhadap keberlangsungan usaha di UMKM Tenun Troso Jepara. Populasi dalam penelitian ini adalah para pelaku UMKM Tenun Troso Jepara dan teknik pengambilan sampel penelitian ini, yaitu purposive sampling dengan 40 responden. Teknik analisis data menggunakan analisis regresi berganda. Hasil penelitian menunjukkan bahwa Covid-19 berpengaruh negatif terhadap keberlangsungan usaha. Semakin lama pandemi Covid-19 tidak tertangani oleh pemerintah, maka akan berdampak keberlangsungan usaha UMKM Tenun Troso Jepara semakin terancam bangkrut. Selain itu, penelitian ini juga menunjukkan bahwa pemanfaatan insentif pajak berpengaruh positif terhadap keberlangsungan usaha. Pemanfaatan PPh UMKM ditanggung pemerintah yang diperpanjang Desember 2020 ternyata berdampak besar terhadap keberlangsungan usaha UMKM Tenun Troso Jepara karena pelaku UMKM tidak perlu melakukan setoran pajak dan pemotong atau pemungut pajak tidak melakukan pemotongan atau pemungutan pajak pada saat melakukan pembayaran kepada pelaku UMKM. Para pelaku UMKM Tenun Troso Jepara sangat mengapresiasi kebijakan pemerintah dengan cara telah memanfaatkan insentif pajak. Penelitian ini mengharapkan adanya sosialisasi atau pendampingan dari KPP Pratama Jepara terkait kebijakan pajak terbaru serta adanya pendampingan dari pihak terkait agar keberlangsungan usaha Tenun Troso Jepara dapat terus terjaga.
\end{abstract}

Kata Kunci: Covid-19; Insentif Pajak; Tenun Troso Jepara

\begin{abstract}
Tenun Troso Jepara is one of the leading products in Jepara Regency. The financial condition of Tenun Troso Jepara MSEMs during the Covid - 19 pandemic has experienced a downturn and this will threaten the business continuity of the Tenun Troso Jepara MSMEs. Government through PMK No. 86 of 2020 has provided tax incentives for MSMEs that have an impact on Covid-19. The purpose of this study was to analyze the impact of Covid-19 and analyze taxes on business continuity at Tenun Troso Jepara MSMEs. The population in this study were the MSMEs Tenun Troso Jepara and the sampling technique was purposive sampling with 40 respondents. The data analysis technique used multiple regression analysis. The results showed that Covid-19 had a negative effect on business continuity. The longer the Covid-19 pandemic is not handled by the government, it will have an impact on the sustainability of MSME businesses. Tenun Troso Jepara
\end{abstract}


is increasingly threatened with bankruptcy. In addition, this study also shows that tax incentives have a positive effect on business continuity. The utilization of PPh UMKM which was borne by the government which was extended in December 2020 turned out to have a major impact on the sustainability of the Tenun Troso Jepara business because MSMEs do not need to make tax deposits and withholding or collecting taxes who do not deduct or collect taxes when making payments to MSMEs. Tenun Troso Jepara MSMEs players highly appreciate government policies by utilizing tax incentives. This research expects socialization or assistance from KPP Pratama Jepara regarding the latest tax policies as well as assistance from related parties so that the continuity of the Tenun Troso Jepara business can be maintained.

Keyword: Covid-19; Tax Incentives; Tenun Troso Jepara

\section{PENDAHULUAN}

Pemerintah Indonesia telah menetapkan wabah penyakit virus corona Covid-19 sebagai status bencana non alam. Dampak dari Covid-19 ini ada yang positif, misalnya adanya peluang-peluang baru terkait akselerasi teknologi khususnya pada bidang usaha dan pendidikan yang semakin berkembang pesat selama pandemi Covid-19. Namun, Covid-19 secara mayoritas berdampak negatif terhadap lingkungan dan masyarakat. Covid-19 telah memperburuk perekonomian Indonesia sehingga masuk dalam fase krisis.

Suryo Utomo (Direktur Jenderal Pajak) menyebutkan adanya tiga dampak besar pandemi Covid-19 terhadap perekonomian Indonesia. Dampak pertama adalah Covid-19 telah membuat konsumsi rumah tangga atau daya beli yang merupakan penopang $60 \%$ perekonomian menurun sangat drastis. Badan Pusat Statistik (BPS) mencatat bahwa konsumsi rumah tangga turun dari 5,02\% pada kuartal I 2019 ke 2,84\% pada kuartal I 2020. Dampak kedua Covid-19, yaitu adanya ketidakpastian yang terus-menerus sehingga membuat investasi semakin melemah dan berdampak pada keberlangsungan usaha yang terancam berhenti. Dampak ketiga Covid-19 adalah penurunan ekonomi yang terjadi di seluruh dunia yang menyebabkan harga komoditas turun dan ekspor Indonesia ke beberapa negara juga terhenti.

Secara umum, Covid-19 berdampak besar terhadap pengelolaan keuangan negara. Pemerintah melakukan perubahan Anggaran Pendapatan dan Belanja Negara (APBN) sebanyak dua kali sebagai upaya pemulihan ekonomi nasional. Pajak yang merupakan penompang perekonomian utama Indonesia juga mengalami imbas dari Covid-19. Penerimaan pajak hingga semester I 2020 hanya mencapai Rp 513,65 triliun atau 44,02\% dari target awal sebesar Rp 1.198,8 triliun. Angka tersebut terkontraksi sampai 12,01\% dibandingkan dengan semester I 2019, yaitu Rp 604,3 triliun. Hal ini disebabkan adanya 
pelemahan di bidang usaha yang mengakibatkan pertumbuhan ekonomi menurun dan berdampak pada penerimaan pajak di Indonesia.

Salah satu upaya pemerintah di bidang perpajakan dalam pemulihan ekonomi nasional adalah adanya kebijakan insentif pajak. Kebijakan insentif pajak ini bertujuan untuk membantu menggerakkan roda perekonomian negara yang mengalami penurunan pesat karena pandemi Covid-19. Kebijakan insentif pajak tertuang dalam Peraturan Menteri Keuangan (PMK) Nomor 86 Tahun 2020. Aturan itu merupakan revisi dari PMK sebelumnya, yaitu PMK Nomor 44 Tahun 2020 tentang insentif pajak untuk wajib pajak terdampak pandemi korona. Lima kebijakan insentif pajak tersebut adalah insentif PPh Pasal 21, PPh Pasal 22 impor, angsuran PPh Pasal 25, pajak UMKM dan PPN.

Berdasarkan PMK Nomor 44 Tahun 2020, pemerintah akan menanggung PPh Final UMKM PP Nomor 23 Tahun 2018 tentang pajak penghasilan atas penghasilan dari usaha yang diterima atau diperoleh wajib pajak yang memiliki peredaran bruto tertentu hingga Desember 2020. Keringanan yang diberikan pemerintah kepada UMKM karena sektor tersebut berkontribusi besar pada Pendapatan Domestik Bruto (PDB) Indonesia, yaitu mencapai $61,7 \%$ atau sekitar Rp 8.952 triliun dari total sebesar Rp 14.837 triliun di tahun 2018. Selain itu, UMKM juga menyerap tenaga kerja hingga 97\% dari total tenaga kerja yang ada.

Pemanfaatan insentif pajak UMKM per 10 Juli 2020 sebanyak 201.880 pelaku. Jumlah ini masih sangat jauh dari total wajib pajak UMKM yang melaporkan PPh pada 2019 sebanyak 2,3 juta wajib pajak UMKM. Peran serta dari pemerintah perlu digencarkan melalui sosialisasi dan pendampingan terkait peraturan pajak terbaru agar para pelaku UMKM bersedia untuk memanfaatkan insentif pajak UMKM dan keberlangsungan UMKM tetap terjaga.

Penelitian ini bertujuan untuk menganalisis dampak Covid-19 dan pemanfaatan insentif pajak terhadap keberlangsungan usaha di UMKM Tenun Troso Jepara. Tenun Troso Jepara merupakan salah satu produk unggulan di Kabupaten Jepara. Tenun Troso sudah ada sejak tahun 1935 yang dimulai dari teknik tenun gedok dan kemudian berkembang menjadi tenun ikat. Sejak adanya Covid-19, kondisi keuangan UMKM Tenun Troso Jepara banyak yang mengalami keterpurukan dan hal ini akan mengancam keberlangsungan usaha para pelaku UMKM Tenun Troso Jepara. Semakin lama pandemi Covid-19, maka akan berdampak keberlangsungan usaha UMKM Tenun Troso Jepara semakin terancam bangkrut.

Pemanfaatan PPh Final UMKM yang ditanggung pemerintah diharapkan dapat membantu UMKM Tenun Troso Jepara dalam mempertahankan keberlangsungan usahanya. 
Pelaku UMKM Tenun Troso Jepara tidak perlu melakukan setoran pajak dan pemotong atau pemungut pajak tidak melakukan pemotongan atau pemungutan pajak pada saat melakukan pembayaran kepada pelaku UMKM. Hal ini dapat memperbaiki kondisi keuangan UMKM.

Penelitian ini mengharapkan adanya sosialisasi atau pendampingan dari KPP Pratama Jepara khususnya terkait kebijakan pajak terbaru serta adanya pendampingan dari pihak terkait agar keberlangsungan usaha UMKM Tenun Troso Jepara dapat terus terjaga dan semakin berkembang. Berdasarkan latar belakang dan tujuan penelitian, maka hipotesis yang diuji dalam penelitian ini adalah:

H1: Dampak Covid-19 berpengaruh negatif terhadap keberlangsungan usaha

H2: Pemanfaatan insentif pajak berpengaruh positif terhadap keberlangsungan usaha

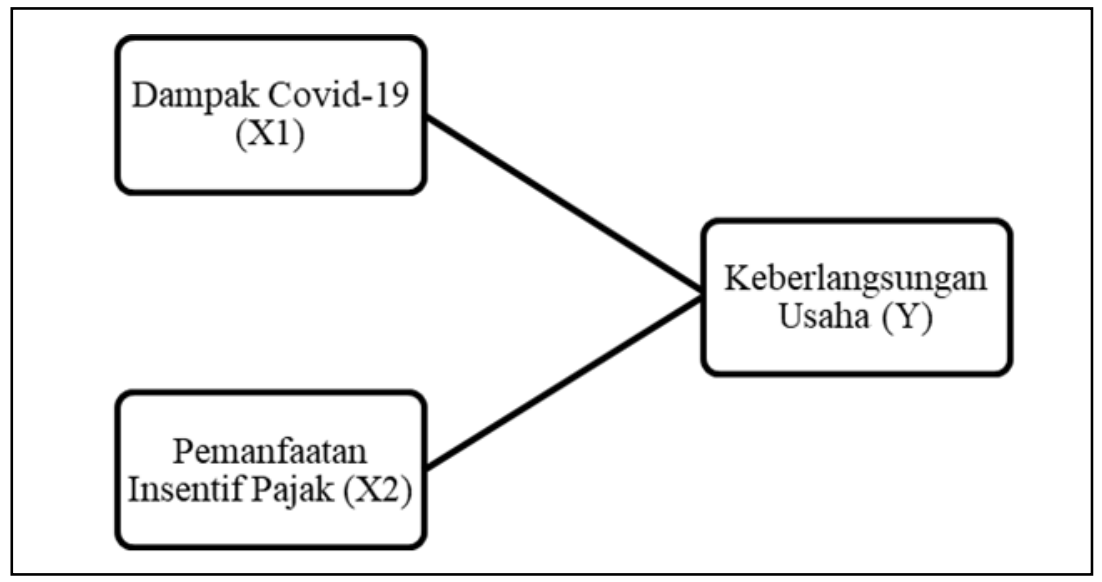

\section{Gambar 1. Kerangka Pemikiran}

\section{METODE PENELITIAN}

Penelitian ini termasuk penelitian kuantitatif dengan fokus mengumpulkan data set dan melakukan generalisasi untuk menjelaskan fenomena khusus yang dialami oleh populasi. Data yang dipakai dalam penelitian ini adalah data primer dengan cara menyebarkan kuesioner langsung kepada responden penelitian.

Variabel independennya, yaitu dampak Covid-19 (X1) dan pemanfaatan insentif pajak (X2), sedangkan variabel dependennya adalah keberlangsungan usaha (Y). Dampak Covid-19 diukur dengan menggunakan empat indikator, yaitu dampak Covid-19 membuat penurunan pendapatan dan jumlah produksi usaha, kenaikan harga bahan baku untuk membuat produk, dan keterlambatan dalam pengiriman bahan baku. Pemanfaatan insentif pajak diukur dengan menggunakan tiga indikator, yaitu tujuan pelaku UMKM dalam memanfaatkan insentif pajak, kebijakan insentif pajak dapat meningkatkan kepatuhan kewajiban perpajakan, dan peran serta pemerintah terkait peraturan atau kebijakan perpajakan terbaru. Keberlangsungan usaha 
diukur dengan menggunakan tiga indikator, yaitu pemenuhan Break Even Point (BEP) selama pandemi Covid-19, kepuasan konsumen, dan karyawan sebagai aset utama. Pengukuran variabel menggunakan skala likert 1 sampai 5 dimana nilai 1 untuk penilaian Sangat Tidak Setuju (STS), nilai 2 untuk penilaian Tidak Setuju (TS), nilai 3 untuk penilaian Netral (N), nilai 4 untuk penilaian Setuju (S), dan 5 untuk penilaian Sangat Setuju (SS).

Populasi dalam penelitian ini adalah para pelaku UMKM Tenun Troso Jepara dan teknik pengambilan sampel penelitian ini, yaitu purposive sampling dengan kriteria para pelaku UMKM Tenun Troso Jepara yang telah memanfaatkan insentif pajak. Responden penelitian yang didapat sebesar 40 responden. Kuesioner penelitian dijawab oleh responden melalui online.

Teknik analisis yang digunakan dalam penelitian ini adalah analisis regresi berganda yang terlebih dahulu dilakukan uji instrumen penelitian (uji validitas dan uji reliabilitas). Kemudian dilakukan uji asumsi klasik (uji normalitas, uji multikolonieritas, dan uji heterokedastisitas), uji kelayakan model (koefisien determinasi dan uji F) dan uji hipotesis.

\section{HASIL DAN PEMBAHASAN}

\section{Hasil Uji Instrumen Penelitian}

\section{Uji Validitas}

Uji validitas dalam penelitian ini digunakan untuk menguji ketepatan dan kecermatan suatu alat ukur dalam melakukan fungsi ukurnya. Suatu indikator penelitian dikatakan valid jika pernyataan dalam penelitian ini mampu untuk mengungkapkan sesuatu yang diukur oleh kuesioner tersebut.

\section{Tabel 1. Hasil Uji Validitas}

\begin{tabular}{|c|c|c|c|c|}
\hline Variabel & Indikator & r hitung & $r$ tabel & Keterangan \\
\hline \multirow[t]{4}{*}{ Dampak Covid-19 } & $\mathrm{X} 1.1$ & 0,443 & 0,312 & Valid \\
\hline & $\mathrm{X} 1.2$ & 0,475 & 0,312 & Valid \\
\hline & $\mathrm{X} 1.3$ & 0,324 & 0,312 & Valid \\
\hline & $\mathrm{X} 1.4$ & 0,647 & 0,312 & Valid \\
\hline Pemanfaatan & $\mathrm{X} 2.1$ & 0,574 & 0,312 & Valid \\
\hline \multirow[t]{2}{*}{ Pajak } & $\mathrm{X} 2.2$ & 0,833 & 0,312 & Valid \\
\hline & $\mathrm{X} 2.3$ & 0,504 & 0,312 & Valid \\
\hline \multirow[t]{3}{*}{ Keberlangsungan Usaha } & Y.1 & 0,488 & 0,312 & Valid \\
\hline & Y.2 & 0,546 & 0,312 & Valid \\
\hline & Y.3 & 0,856 & 0,312 & Valid \\
\hline
\end{tabular}

Sumber: data diolah, 2020 
Berdasarkan Tabel 1 terlihat seluruh $\mathrm{r}_{\text {hitung }}$ lebih besar dari $\mathrm{r}_{\text {tabel }}$ dengan product moment $=0,312(\alpha=5 \%, \mathrm{df}=\mathrm{n}-2=40-2=38)$, maka dapat dikatakan bahwa butir pernyataan indikator penelitian yang digunakan adalah valid.

\section{Uji Reliabilitas}

Uji reliabilitas dilakukan dengan menghitung koefisien (cronbach) alpha dari masingmasing instrumen dalam satu variabel. Instrumen yang dipakai dalam variabel tersebut dikatakan andal (reliabel) jika memiliki koefisien cronbach alpha lebih dari 0,60.

Tabel 2. Hasil Uji Reliabilitas

\begin{tabular}{lcc}
\hline \multicolumn{1}{c}{ Variabel } & Cronbach Alpha & Hasil \\
\hline Dampak Covid-19 & 0,762 & Reliabel \\
Pemanfaatan Insentif Pajak & 0,635 & Reliabel \\
Keberlangsungan Usaha & 0,867 & Reliabel \\
\hline
\end{tabular}

Sumber: data diolah, 2020

Tabel 2 menyimpulkan bahwa variabel dampak covid-19 (X1), pemanfaatan insentif pajak (X2), dan keberlangsungan usaha (Y) masing-masing memiliki nilai cronbach alpha lebih besar dari 0,60, maka dapat diartikan bahwa seluruh indikator penelitian andal (reliabel) untuk digunakan sebagai alat ukur.

\section{Hasil Uji Asumsi Klasik}

\section{Uji Normalitas}

Uji normalitas bertujuan untuk menguji apakah dalam model regresi, variabel pengganggu atau residual memiliki distribusi normal. Untuk menguji apakah data berdistribusi normal atau tidak dilakukan uji statistik One Sample Kolmogorov-Smirnov Test. Data berdistribusi normal jika memiliki nilai signifikansi lebih besar dari 0,05.

\section{Tabel 3. Hasil Uji Normalitas}

\section{Unstandardized Residual}

\begin{tabular}{lr}
\hline $\mathrm{N}$ & 40
\end{tabular}

Asymp. Sig. (2-tailed) 0,200

Sumber: data diolah, 2020

Pada Tabel 3 menunjukkan bahwa nilai signifikansi dari uji normalitas yang dilakukan mempunyai nilai sebesar 0,200, dimana 0,200 lebih besar dari 0,05 , sehingga data terdistribusi normal.

\section{Uji Multikolonieritas}

Uji multikolonieritas dilakukan untuk menguji apakah dalam suatu model regresi 
ditemukan adanya korelasi antar variabel independen atau tidak. Model regresi dikatakan baik jika korelasi antar sesama variabel independen mendekati nol atau tidak ada korelasi. Ada tidaknya multikolinearitas dapat dilihat dari besarnya Toleranc Value dan Variance Inflation Factor (VIF). Jika nilai Tolerance Value lebih besar dari 0,10 dengan nilai VIF kurang dari sama dengan 10, maka dinyatakan tidak terjadi multikolinieritas.

Tabel 4. Hasil Uji Multikolonieritas

\begin{tabular}{ccc}
\hline \multirow{2}{*}{ Model } & \multicolumn{2}{c}{ Collinearity Statistics } \\
& Tolerance & VIF \\
\hline Dampak Covid-19 & 0,667 & 1,657 \\
Pemanfaatan Insentif Pajak & 0,143 & 7,332 \\
\hline
\end{tabular}

Sumber: data diolah, 2020

Berdasarkan Tabel 4 menunjukkan nilai dari masing-masing variabel independen sebesar Tolerance lebih besar dari 0,10 dan nilai VIF kurang dari sama dengan 10 yang artinya bahwa seluruh variabel independen dalam penelitian ini tidak terjadi multikolinieritas.

\section{Uji Heteroskedastisitas}

Uji heteroskedastisitas dilakukan untuk mengetahui apakah dalam model regresi yang digunakan terjadi ketidaksamaan varian dari residual satu pengamatan ke pengamatan yang lain. Model regresi yang baik adalah model regresi yang memiliki varian dari residual satu pengamatan ke pengamatan yang lain tetap. Jika nilai signifikansi lebih besar dari 0,05 , maka data tidak terjadi heterokedastisitas.

\section{Tabel 5. Hasil Uji Heteroskedastisitas}

\begin{tabular}{lcc}
\hline \multicolumn{1}{c}{ Variabel } & Sig & Keterangan \\
\hline kDampak Covid-19 & 0,656 & Tidak terjadi heteroskedastisitas \\
Pemanfaatan Insentif Pajak & 0,587 & Tidak terjadi heteroskedastisitas \\
\hline
\end{tabular}

Sumber: data diolah, 2020

Pada Tabel 5 menunjukkan bahwa semua variabel independen memiliki nilai probabilitas signifikansi yang lebih besar dari 0,05 , sehingga dapat disimpulkan bahwa tidak terjadi heteroskedastisitas dalam model regresi tersebut.

\section{Analisis Regresi Berganda}

Analisis regresi berganda ini digunakan untuk mengetahui arah hubungan antara variabel independen dengan variabel dependen apakah masing-masing variabel independen berhubungan positif atau negatif dan untuk memprediksi nilai dari variabel dependen apabila nilai variabel independen mengalami kenaikan atau penurunan. 
Tabel 6. Hasil Uji Regresi Berganda

\begin{tabular}{llcrr}
\hline \multirow{2}{*}{ Model } & \multicolumn{2}{c}{ Unstandardized Coefficients } & $\begin{array}{c}\text { Standardized } \\
\text { Coeffocients }\end{array}$ \\
\cline { 3 - 5 } & & B & Std. Error & Beta \\
\hline 1 & (Constant) & 2,848 & 2,415 & \\
& Dampak Covid-19 & $-0,002$ & 0,075 & $-0,002$ \\
& Pemanfaatan Insentif Pajak & 0,424 & 0,154 & $-0,324$ \\
\hline
\end{tabular}

Sumber: data diolah, 2020

Berdasarkan Tabel 6 didapat model persamaan:

$\mathrm{Y}=2,848-0,002 \mathrm{X}_{1}+0,424 \mathrm{X}_{2}+\mathrm{e}$

\section{Uji Kelayakan Model}

\section{Koefisien Determinasi $\left(\mathbf{R}^{2}\right)$}

Koefisien determinasi $\left(\mathrm{R}^{2}\right)$ dipergunakan untuk mengetahui seberapa besar persentase variasi variabel dependen pada model dapat diterangkan oleh variabel independen.

Tabel 7. Hasil Uji Koefisien Determinasi

\begin{tabular}{rrrrr}
\hline Model & R & R Square & $\begin{array}{c}\text { Adjusted R } \\
\text { Square }\end{array}$ & \multicolumn{1}{c}{$\begin{array}{c}\text { Std. Error of } \\
\text { the Estimate }\end{array}$} \\
\hline 1 & 0,129 & 0,132 & 0,112 & 0,21056
\end{tabular}

Sumber: data diolah, 2020

Besarnya koefisien determinasi atau $\mathrm{R}^{2}$ pada Tabel 7 sebesar 0,132 atau 13,2\% yang dapat diartikan bahwa 13,2\% variasi variabel dependen pada model dapat diterangkan oleh variabel independen penelitian, sedangkan sisanya $86,8 \%$ dipengaruhi oleh variabel lain di luar model.

\section{Uji F}

Uji F digunakan untuk menguji apakah variabel dampak Covid-19 dan pemanfaatan pajak memiliki pengaruh terhadap variabel keberlangsungan usaha.

Tabel 8. Hasil Uji F

\begin{tabular}{llrrrrr}
\hline & Model & \multicolumn{1}{c}{ Sum of Squares } & Df & Mean Squares & \multicolumn{1}{c}{ F } & Sig. \\
\hline 1 & Regression & 580,209 & 3 & 145,052 & 98,980 &, 000 \\
& Residual & 51,291 & 36 & 1,465 & & \\
Total & 631,500 & 39 & & &
\end{tabular}


Berdasarkan Tabel 8 didapatkan nilai $\mathrm{F}$ statistik untuk persamaan pertama sebesar 98,980 bertanda positif dengan nilai signifikansi 0,000 lebih kecil dari 0,05, maka dapat disimpulkan bahwa dampak Covid-19 dan pemanfaatan pajak secara bersama-sama berpengaruh positif terhadap keberlangsungan usaha.

\section{Uji Hipotesis (Uji t)}

Uji t dilakukan untuk membuktikan kebenaran dari hipotesis.

Tabel 9. Hasil Uji t

\begin{tabular}{lrr}
\hline Variabel & T & \multicolumn{2}{c}{ Sig. } \\
\hline Dampak Covid-19 & $-3,231$ & 0,003 \\
Pemanfaatan Insentif Pajak & 6,540 & 0,000
\end{tabular}

Sumber: data diolah, 2020

Pada Tabel 9 dapat dilihat bahwa dampak Covid-19 dan pemanfaatan insentif pajak mempunyai nilai signifikansi lebih kecil dari 0,05, sehingga dapat disimpulkan bahwa dampak Covid-19 dan pemanfaatan insentif pajak mempunyai pengaruh terhadap keberlangsungan usaha.

Hasil penelitian membuktikan bahwa dampak Covid-19 berpengaruh negatif terhadap keberlangsungan usaha, sehingga hipotesis pertama diterima. Jika Covid-19 tidak segera ditangani oleh pemerintah, maka keberlangsungan usaha UMKM Tenun Troso Jepara semakin terancam. Rata-rata responden penelitian merasa keterlambatan dalam hal pengiriman bahan baku menjadi masalah penting selama pandemi Covid-19 karena pemerintah menerapkan Pembatasan Sosial Berskala Besar (PSBB) di berbagai daerah dan menyebabkan supplier bahan baku tidak maksimal dalam pengirimannya. Apabila pengiriman bahan baku mengalami keterlambatan, maka jumlah produksipun akan mengalami penurunan dan ini akan berimbas pada pendapatan UMKM Tenun Troso Jepara juga mengalami penurunan.

Hipotesis kedua penelitian juga diterima, di mana pemanfaatan insentif pajak berpengaruh positif terhadap keberlangsungan usaha. Kebijakan insentif pajak, yaitu $\mathrm{PPh}$ Final UMKM yang ditanggung pemerintah dengan tujuan untuk keberlangsungan bisnis UMKM sangat mendorong partisipasi UMKM Tenun Troso Jepara. Para pelaku UMKM Tenun Troso Jepara mengapresiasi kebijakan insentif pajak dengan cara telah memanfaatkan insentif pajak tersebut serta terus meningkatkan kepatuhan kewajiban perpajakannya. Kebijakan insentif pajak ini dianggap mampu membantu kondisi keuangan para pelaku UMKM Tenun Troso Jepara karena pajak UMKM ditanggung sepenuhnya oleh pemerintah. 


\section{KESIMPULAN}

Berdasarkan hasil pengolahan dan analisis data yang telah dilakukan dalam penelitian ini, maka dapat ditarik kesimpulan bahwa variabel dampak Covid-19 berpengaruh negatif terhadap keberlangsungan usaha UMKM Tenun Troso Jepara, sedangkan variabel pemanfaatan insentif pajak berpengaruh positif terhadap keberlangsungan usaha UMKM Tenun Troso Jepara.

Keterbatasan dalam penelitian ini adalah masih rendahnya nilai R2 yaitu sebesar 13,2\% dan kurangnya sampel penelitian karena pada saat penelitian Kabupaten Jepara sedang berada di zona merah Covid-19 dan para pelaku UMKM Tenun Troso Jepara banyak yang belum mengerti teknologi. Agar mendapatkan hasil yang lebih baik lagi, maka saran dalam penelitian ini adalah penambahan variabel independen lainnya, seperti kondisi keuangan.

\section{REFERENSI}

Aribawa, D. (2016). Pengaruh Literasi Keuangan terhadap Kinerja dan Keberlangsungan UMKM di Jawa Tengah. Jurnal Siasat Bisnis 20(1), 1-13.

Aryandini, S. (2016). Pengaruh Kewajiban Moral, Pemeriksaan Pajak, dan Kondisi Keuangan terhadap Kepatuhan Wajib Pajak Badan Usaha Hotel yang Terdaftar di Dinas Pendapatan Daerah Kota Pekanbaru. JOM Fekon 3(1), 1463-1477.

Ardayani, P. V. N., \& Jati, I. K. (2019). Pengaruh Tax Amnesty dan Kondisi Keuangan pada Tingkat Kepatuhan Wajib Pajak Orang Pribadi. E-Jurnal Akuntansi Universitas Udayana 26(3), 1741-1768.

Ghozali, I. (2013). Aplikasi Analisis Multivariate dengan Program IBM SPSS 21. Semarang: Badan Penerbit Universitas Diponegoro.

Sarmigi, E. (2020). Analisis Pengaruh Covid-19 terhadap Perkembangan UMKM di Kabupaten Kerinci. Al-Dzahab 1(1), 1-17. 